\title{
STATUS OF MICROALBUMIN IN HYPERTENSIVE PATIENT
}

\section{Shekhar Chandra Yadav and Ritu Yadav}

\begin{abstract}
:
Hypertension is one of the major risk factor for an increased risk of stroke, myocardial infarction, end-stage renal disease, congestive heart failure and peripheral vascular disease. The kidney is a main target of organ damage in hypertension. Microalbuminuria is one of the earliest indications of kidney injury in patients with hypertension. Total of 50 cases and 50 controls are enrolled into the study. Their blood pressure was measured and spot urine sample was analyzed for Microalbumin. Blood pressure and Microalbumin were statically elevated in case group in comparison to control group.
\end{abstract}

Key Words: Microalbumin.hypertension

\section{Introduction:}

The hypertension was defined according to Fifth report of Joint National Committee for detection, evaluation and treatment of high blood pressure, as systolic blood pressure more than or equal to $140 \mathrm{~mm}$ of $\mathrm{Hg}$ and diastolic blood pressure more than or equal to $90 \mathrm{~mm}$ of $\mathrm{Hg}$ or those individuals currently taking antihypertensive treatment. ${ }^{1}$

Hypertension is becoming an important public health problem worldwide. A recent report on the global burden of hypertension indicates that nearly 1 billion adults (more than a quarter of the world's population) had hypertension in 2000, and this is predicted to increase to 1.56 billion by $2025 .^{2}$

Hypertension also known as high blood pressure is one of the most common complex and public health problems which becomes more prevalent in developed and developing countries. $^{3}$

Hypertension has been named the "silent killer," as it is the major contributor-or risk factor-to cardiovascular morbidity and mortality. Although the causes-genetic and environmental-remain obscure, much progress has been made in elucidating some of the pathogenic mechanisms causing hypertension, as well as its common complications, i.e. Ischemic heart disease, stroke and renal failure. $^{4}$

Microalbuminuria is defined as the excretion of 30 to $300 \mathrm{mg}$ of albumin per day in urine. It is not a different form or fraction of albumin but just a very small amount of albumin. Albumin molecule is relatively small and it is often the first protein to enter the urine after the kidney is damaged.

Glomerular hyperfiltration may be a second mechanism linking the higher level of albumin excretion with hypertension which reduces nephron number and /or increases activity of kidney rennin-angiotensin system, may provide a link between higher levels of albumin excretion and the development of hypertension, among at high baseline risk for cardiovascular events. ${ }^{7}$ 
Microalbuminuria not only predicts the cardiovascular risk but also seems to be a sensitive marker for detecting new onset of other cardiovascular events like hypertension. Brantsma et al, found that microalbuminuria increased the risk of hypertension by two fold as compared to normal albuminuria levels. ${ }^{8}$

The association between microalbuminuria and hypertension was described by Parving et al, in 1974, microalbuminuria has a major impact on cardiovascular risk and become a prognostic marker for cardiovascular disorder, in essential hypertensive an increased transglomerular passage of albumin may result from several mechanisms like hyperfiltration, glomerular basal membrane abnormalities, endothelial dysfunction and nephrosclerosis. Microalbuminuria has been proved to be a prognostic marker for the development of nephropathy in long standing diabetes patients. ${ }^{9}$

\section{Material and method:}

The present study was carried out on total 100 subjects, which were divided into two groups:

a) Case groups (Hypertensive Subjects), $n=$ 50

b) Control groups (Non Hypertensive Subjects), $n=50$ with no present and past family history of hypertension.

Subject with Diabetes mellitus, Cardiac patients, Alcoholic patients, Smokes, Renal failure, patient with nephropathy were excluded from the study. Spot urine sample was collected from the subject in container for the estimation of urine microalbumin level

Sample was analysed by using biochemistry auto analyzer. Bs-300 chemistry analyzer (Mindray) was used for the analysis of the urine microalbumin. Immunoturbidimetric method was used to estimate the level of microalbimin. ${ }^{10}$

\section{Result:}

The present study is case control study where microalbuminuria was estimated, compared and correlated in hypertensive case group with healthy normotensive group. This was carried out on total 100 subjects, which were divided into two groups-case group consists of 50 subjects of known hypertensive patient and control group consists of 50 subjects who were healthy normotensive.

Table 1: Shows that the Mean age group of case study was $33.38 \pm 5.33$, in which the age group consisted $34 \%$ of $25-30$ years, $54 \%$ where in age group of 31-40 years, followed by $12 \%$ in the range of $41-50$ years. Whereas the control group Mean was 33.84 \pm 5.15 , consisting of 28\% age group of 25-30 years, $58 \%$ seen in $31-40$ years remaining $14 \%$ in 41 50 years age group. Suggesting the samples were age matched with $\mathrm{p}=0.662$

Table 1: Age distribution of subject studied

\begin{tabular}{|c|c|c|c|c|}
\hline \multirow{2}{*}{$\begin{array}{c}\text { Age } \\
\text { in } \\
\text { years }\end{array}$} & \multicolumn{2}{|c|}{ Control } & \multicolumn{2}{c|}{ Cases } \\
\cline { 2 - 5 } & No & $\%$ & No & $\%$ \\
\hline $25-30$ & 14 & 28.0 & 17 & 34.0 \\
\hline $31-40$ & 29 & 58.0 & 27 & 54.0 \\
\hline $41-50$ & 7 & 14.0 & 6 & 12.0 \\
\hline Total & 50 & 100.0 & 50 & 100.0 \\
\hline $\begin{array}{c}\text { Mean } \\
\pm \text { SD }\end{array}$ & $33.84 \pm 5.15$ & $33.38 \pm 5.33$ \\
\hline
\end{tabular}

Samples are age matched with $\mathrm{p}=0.662$

Table 2: The percentage of gender studied showed that the control group with 50\% male and $50 \%$ female when compared to case group male $54 \%$ and $46 \%$ female. Gender distribution was statistically similar between two groups with $p=0.689$. Hence in the present study there is no significant difference in the 
prevalence of hypertension in between males and females.

Table 2: Gender distribution of subject studied

\begin{tabular}{|l|c|c|c|c|}
\hline \multirow{2}{*}{ Gender } & \multicolumn{2}{|c|}{ Control } & \multicolumn{2}{c|}{ Cases } \\
\cline { 2 - 5 } & No & $\%$ & No & $\%$ \\
\hline Male & 25 & 50.0 & 27 & 54.0 \\
\hline Female & 25 & 50.0 & 23 & 46.0 \\
\hline Total & 50 & 100.0 & 50 & 100.0 \\
\hline
\end{tabular}

Samples are gender matched with $p=0.689$

Table 3: Shows that microalbumin levels in urine were $100 \%$ in normal range $(<30 \mathrm{mg} / \mathrm{l})$ in control, whereas the levels where $100 \%$ in higher range $(>30 \mathrm{mg} / \mathrm{l})$ in case group. Thus explaining that in case group there was significantly elevated urine microalbumin levels when compared to controls with $\mathrm{p}<0.001$.

Table 3: Levels of microalbumin in urine in case and control

\begin{tabular}{|c|c|c|c|c|}
\hline \multirow{2}{*}{$\begin{array}{l}\text { Urine } \\
\text { micro } \\
\text { albumin }\end{array}$} & \multicolumn{2}{|c|}{ Control } & \multicolumn{2}{|c|}{ Cases } \\
\hline & No & $\%$ & No & $\%$ \\
\hline $\begin{array}{l}<30 \\
\mathrm{mg} / \text { liter }\end{array}$ & 50 & 100.0 & 0 & 0.0 \\
\hline $\begin{array}{l}>30 \\
\mathrm{mg} / \text { liter }\end{array}$ & 0 & 0.0 & 50 & 100.0 \\
\hline Total & 50 & 100.0 & 50 & 100.0 \\
\hline Inference & $\begin{array}{r}\text { Uri } \\
\text { sigi } \\
\mathrm{cc}\end{array}$ & $\begin{array}{l}\text { nicro- } \\
\text { antly } \\
\text { ared } \\
\mathrm{p}<\end{array}$ & $\begin{array}{l}\min \\
\text { ated } \\
\text { ntrol } \\
* *\end{array}$ & $\begin{array}{l}\text { els is } \\
\text { cases } \\
\text { ith }\end{array}$ \\
\hline
\end{tabular}

Table 4: Shows the comparison of Mean values of urine microalbumin in two groups studied where Microalbuminuria is significantly increased in case group with the Mean of $171.26 \pm 348.93$ when compared to control group Mean of $14.36 \pm 8.78$ with $p=$
0.002 . Thus showing a strong significant levels of urine microalbumin in cases when compared to control group.

Table 4: Mean levels of urine microalbumin in two groups

\begin{tabular}{|l|c|l|c|}
\hline & Controls & Cases & $\begin{array}{c}\text { P } \\
\text { value }\end{array}$ \\
\hline $\begin{array}{l}\text { Urine } \\
\text { microalbu } \\
\text { min }\end{array}$ & $\begin{array}{c}14.36 \pm 8 . \\
78\end{array}$ & $\begin{array}{c}171.26 \pm 348 \\
.93\end{array}$ & $\begin{array}{c}0.002 \\
* *\end{array}$ \\
\hline
\end{tabular}

\section{Disscussion:}

Hypertension is a major public health problem in India and in other developing countries. Hypertension affects approximately $25 \%$ of the adult population worldwide and its prevalence is predicted to increase by $60 \%$ by 2025 A.D. ${ }^{11}$

High blood pressure is an important independent predictor of the development and progression of chronic renal disease as well as morbidity and mortality in patients with chronic renal disease. ${ }^{12}$

The risk of renal failure associated with less severe hypertension is graded and continuous throughout the distribution of blood-pressure readings above the optimal level, making the kidney considered a target organ for hypertension . ${ }^{13}$

The increasing interest in the significance of Microalbuminuria in essential hypertension, is associated with an increased incidence of cardiovascular complications and morbid events, such as left ventricular hypertrophy, coronary heart disease, carotid artery thickness,renal failure and hypertensive retinopathy. ${ }^{14}$

In our study levels of urine microalbumin were significantly high in hypertensive patients 
compared to non hypertensive patients which is matched with previous studies. ${ }^{15,16}$

\section{References:}

1. Sampatti Sambhaji Todkar, Venktesh V Gujarathi1, et al. "Period Prevalence and Sociodemographic Factors of Hypertension in Rural Maharashtra: A Cross- Sectional Study" Indian Journal of Community Medicine, July2009; vol 3: 34.

2. Kearney PM, Whelton M, et al. "Global burden of hypertension: analysis of worldwide data" Lancet 2005; 365: 217-23.

3. Modupe Fisayo ASAOLU, Samuel Sunday ASAOLU, et al. "Evaluation of elements in the pathogenesis of hypertension in Nigerians" September-October 2010; 4(2).

4. Haralambos Gavras. "Pathogenesis of Hypertension: A Review" Journal of Medical Sciences (2009); 2(1): 25-28.

5. David BS. "Carbohydrates" In: Burtis AC, Ashwood RE, editors. Tietz text book of clinical chemistry $3^{\text {rd }}$ edn: Philadelphia: Saunders; 1999: 798-801.

6. Bilous RW. "Diabetes mellitus and the kidneys" In: Warell DA, Cox TM, Firth JD, Jr. Benz Edwards J, editors. Oxford Text Book of Medicine 4th edn: New York. Oxford University Press 2003; 374-380.

7. John P Forman, Naomi D.L. Fisher et al. "Higher levels of Albuminuria within the normal range predict incident hypertension." J Am Soc Nephrol, 2008; 19:1983-1988.

8. Dick de Zeeuw, Hans-Henrik Parving et al. "Microalbuminuria as an Early Marker for cardiovascular Disease." J Am Soc Nephrol, 2006; 17: 2100-2105.

9. Ravjit Kaur Sabharwal, Parduman Singh et.al. "Incidence of Microalbuminuria in Hypertensive Patients." Indian Journal of Biochemistry, 2003; 23(1): 71-75.

10. Diasys diagnostic systems $\mathrm{GmbH}$ alte strasse 9 65558 Holzheim Germany "Albumin in Urine/CSF FS (Microalbuminuria)" 2008: 1-2.

11. Kearney PM, Whelton M, et al. "Global burden of hypertension: analysis of world wide data" Lancet, 2005; 365: 217-223.

12. Whelton PK, Klag MJ. "Hypertension as a risk factor for renal disease: review of clinical and epidemiological evidence" Hypertension, 1989; 13: 119-127.

13. Nicolas Roberto Robles, Juan F. Sanchez Munoz Torrero, et al. "Prevalence and significance of mild renal dysfunction in a group of hypertensive patients followed -up in Hypertension Units" Port J Nephrol Hypert, 2010; 24(2): 153-157.

14. Vito M. Campese, Stefano Bianchi et al. "Is microalbuminuria a predictor of cardiovascular and renal disease in patients with essential hypertension?" Current Opinion in Nephrology and Hypertension, 2000; 9:143-147.

15. John P Forman, Naomi D.L. Fisher et al. "Higher levels of Albuminuria within the normal range predict incident hypertension." J Am Soc Nephrol, 2008; 19:1983-1988.

16. Kathleen D. Pagana, RN, PhD. "Microalbumin: Little test, big payoff" American Nurse Today, October 2006.

Address of Correspondence: Shekhar Chandra Yadav, Lecturer, Department of Microbiology, Nobel Medical College, Biratnagar-5 